\title{
Druglikeness of Flowerophoric Model
}

\section{Kavita Bisht ${ }^{1}$, Alok maithani², Luv Kush³}

${ }^{1}$ M.Sc. Pharmaceutical Chemistry, Sardar Bhagwan Singh University, Balawala Dehradun-248161, Uttarakhand, India

${ }^{2}$ Assistant Professor, Dept. of Applied Chemistry, SBS, Balawala Dehradun-248161, Uttarakhand, India

${ }^{3}$ Academic Advisor Cum Educator, Deptt of Applied Chemistry, SBS University, Balawala Dehradun-248161, Uttarakhand, India

\section{A B S T R A C T}

Angiospermic biodiversity is composed of extraordinary versatile flowers of different shapes, colors and aromas. Recently flowers have emerged as the complementary medicine. The druglikeness of commonly occurring terpenoids, flavonoids and pigments in the flowers was rationalized to suggest flowerophoric model at naturotherapeutical level.

Keywords- Druglikeness, Flowerophoric, Lipinski's rule, Natural product, Naturotherapeutical.

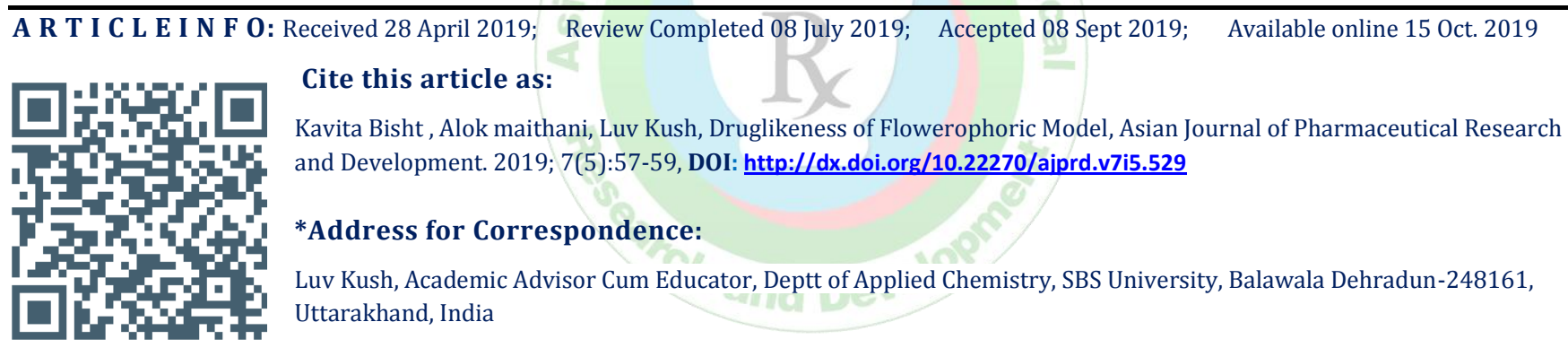

\section{INTRODUCTION}

$\mathrm{T}$ he medicinal relevance of flowers ${ }^{1-9}$ is authenticated by multiple bioactivities of naturotherapeutical significance,. The natural product chemistry of medicinal flowers ${ }^{10-14}$ have organic structures of terpenoids, flavonoids and pigments as well as functional nutrients (vitamins, minerals). The pollen garins ${ }^{15-17}$ are the rich source of nutraceuticals and novel chemical entities. Recently flower therapy ${ }^{18}$ is found to be quite effective for the emotional and social welfares of the people. The druglikeness is the focal point to be rationalized for their value as the naturotherapeuticals.

\section{Theoretical Methodology}

Lipinski's rule ${ }^{19}$ and veber's ${ }^{20}$ rule ascertain the druglikeness for the pharmacokinetic compliance. We selected total ten compounds of different organic structures which commonly occur in almost every flower. The data of both the rules is given in tables $1 \& 2$.

\section{RESULT AND DISCUSSION}

The Flowers therapeutics is based on chromogenic and perfumogenic chemical entitles for the naturopathy. The flowerophoric model is analogues to pharmacophore ${ }^{21}$ and ayurvedicophore $e^{22,23}$ because druglikeness of chemical structures of terpenoids, flavonoids, and pigments was rationalized for the pharmacokinetic compliance. The molecular mass, H-bond acceptors and donors showed satisfactory compliance with Lipinski's rule except pigments, therefore terpenoids and flavonoids have better druglikeness than pigments. Veber's modification data suggested violation of the rule of molecular flexibility by Lycopene. The flowerophoric model for binding at site of action should be composed of optimal hydrophobic surface 
to accommodate alkyl, acyclic and aryl structural moieties. The dominance of oxygen functions may act both as $\mathrm{H}$ bond acceptor and donor. Interestingly profound unsaturation due to пbonds impart high degree of planarity, for intercalative action.

Table 1: Lipinski's rule related data

\begin{tabular}{|c|c|c|c|c|c|c|c|c|c|c|}
\hline $\begin{array}{l}\text { Pharmac } \\
\text { Ophoric } \\
\text { properties }\end{array}$ & Anthocyanin & B- carotone & $\begin{array}{l}\text { Caryop } \\
\text { hyllene }\end{array}$ & Delphinidin & Kaempf erol & Lycopene & Linalool & Nerolidol & Quercetin & Zeaxanthin \\
\hline $\begin{array}{l}\text { Molecular } \\
\text { formula }\end{array}$ & $\mathrm{C}_{15} \mathrm{H}_{11} \mathrm{O}$ & $\mathrm{C}_{40} \mathrm{H}_{56}$ & $\mathrm{C}_{15} \mathrm{H}_{24}$ & $\mathrm{C}_{15} \mathrm{H}_{11} \mathrm{O}_{7}$ & $\mathrm{C}_{15} \mathrm{H}_{10} \mathrm{O}_{6}$ & $\mathrm{C}_{40} \mathrm{H}_{56}$ & $\mathrm{C}_{10} \mathrm{H}_{18} \mathrm{O}$ & $\mathrm{C}_{15} \mathrm{H}_{26} \mathrm{O}$ & $\mathrm{C}_{15} \mathrm{H}_{10} \mathrm{O}_{7}$ & $\mathrm{C}_{40} \mathrm{H}_{56} \mathrm{O}_{2}$ \\
\hline $\begin{array}{l}\text { Molecular } \\
\text { weight }\end{array}$ & $\begin{array}{l}207.252 \\
\mathrm{~g} / \mathrm{mol}\end{array}$ & $\begin{array}{l}536.8 \\
\mathrm{~g} / \mathrm{mol}\end{array}$ & $\begin{array}{l}204.357 \\
\mathrm{~g} / \mathrm{mol}\end{array}$ & $\begin{array}{l}303.24 \\
3 \mathrm{~g} / \mathrm{mol}\end{array}$ & $\begin{array}{l}286.236 \\
\mathrm{~g} / \mathrm{mol}\end{array}$ & $\begin{array}{l}536.87 \\
3 \mathrm{~g} / \mathrm{mol}\end{array}$ & $\begin{array}{l}154.25 \\
3 \mathrm{~g} / \mathrm{mol}\end{array}$ & $\begin{array}{l}222.3 \\
6 \mathrm{~g} / \mathrm{mol}\end{array}$ & $\begin{array}{l}302.23 \\
8 \mathrm{~g} / \mathrm{mol}\end{array}$ & $\begin{array}{l}568.8 \\
7 \mathrm{~g} / \mathrm{mol}\end{array}$ \\
\hline $\begin{array}{l}\text { No. of Chiral } \\
\text { atom }\end{array}$ & 0 & 0 & 2 & 0 & 0 & 0 & 1 & 1 & 0 & 0 \\
\hline $\begin{array}{l}\text { H-bond } \\
\text { acceptors }\end{array}$ & 0 & 0 & 0 & 6 & 6 & 0 & 1 & 1 & 7 & 2 \\
\hline $\begin{array}{l}\text { H-bond } \\
\text { Donors }\end{array}$ & 0 & 0 & 0 & 6 & 4 & 0 & 1 & 1 & 5 & 2 \\
\hline $\begin{array}{l}\text { Log-p } \\
\text { value }\end{array}$ & 4.47 & 9.72 & 4.52 & 2.07 & 1.99 & 9.16 & 2.68 & 4.55 & 2.16 & 8.3 \\
\hline
\end{tabular}

Table 2: Veber's rule related data

\begin{tabular}{|c|c|c|c|c|c|c|c|c|c|c|}
\hline $\begin{array}{l}\text { Pharmac } \\
\text { Ophoric } \\
\text { properties }\end{array}$ & Anthocyanin & B- carotone & $\begin{array}{l}\text { Caryop } \\
\text { hyllene }\end{array}$ & Delphinidin & Kaempferol & Lycopene & Linalool & Nerolidol & Quercetin & $\begin{array}{l}\text { Zeaxan } \\
\text { thin }\end{array}$ \\
\hline $\begin{array}{l}\text { No. of Aryl } \\
\text { rings }\end{array}$ & 3 & 2 & 0 & 3 & 3 & 0 & 0 & 0 & 3 & 2 \\
\hline $\begin{array}{l}\text { Sum of H- } \\
\text { Bond donors } \\
\& \text { acceptors }\end{array}$ & 0 & 0 & 0 & 12 & 10 & 0 & 2 & 2 & 12 & 4 \\
\hline $\begin{array}{l}\text { Rotable bond } \\
\text { count }\end{array}$ & 1 & 10 & 0 & 1 & 1 & 16 & 4 & 7 & 1 & 10 \\
\hline
\end{tabular}

\section{CONCLUSION}

Flower therapeutics is the future of naturotherapeutics. Flowers are integral part of human love, romance, friendship, respect and worship. They have remarkable chemical entities of druglikeness, gifted by nature. The druglikeness of ten compounds was theoretically evaluated fo the pharmacokinetic compliance. A flowerophoric model was suggested, composed of hydrophobic, H-bond acceptor and donor binding sites for bioaction. The flowerophoric model may innovate rational use for emotional and social welfares of human life.

\section{ACKNOWLEDGMENT}

The authors express their gratefulness to Mr. S.P. Singh Chancellor of SBS University, who splendidly added flowery charm to our campus. It was source of inspiration for this publication. Mrs. Nalini Mehrishi, guide to flower shows and displays, is greatly appreciated for supporting the disseminating knowledge of flowers.

\section{REFERENCES}

1. Roberts M.J., Edible and Medicinal flowers, Introduction page, VI, Spearhead Publications, \#99, Garfield-7708, United States of America, 2000.

2. Sanjay Kr. Uniyal. KN Singh, Pankaj Jamwal and Brij Lal. Traditional use of medicinal plants among the tribal communities of Chhota Bhangal. Western Himalaya. Journal of Ethnobiology and Ethnomedicine.2006; 2:14-21.
3. Parameshwaran K., Flower therapy, Delhi, Govt of India.http://pjb.nic.in/feature/feyr2001/fnov2001/f061120011.html.20 01.

4. Varadhan, K.P. introduction to Pushpa Ayurveda, Ancient science of life 4(3):153-571985.

5. Therapeutic uses of flowers leads from traditional system of medicine, International journal of herbal medicine, www.florajournal.com

6. Anagha B. Kothadia. Flower Power, Heritage Amruth,2011;7(2):4749.

7. Khare C.P. Indian Medicinal plants, An illustrated Dictionary, Springer science (India) Pvt. Ltd. 2007.

8. Ashok Sheth, The Herbs of, Vol. I-IV, Ashok K. Sheth, "Alankar", 1157, Near Meghani Circle , Bhavanagar-364001, Gujarat, India,2005.

9. M.N. Shubhashree, J. Res. Educ. Indian Med., Vol. Xxi Jan-March 2015 A Review On Therapeutic Uses Of Flowers As Depicted In Classical Texts Of Ayurveda And Siddha.

10. Chatterjee A, Pakrashi SC. The Treatise on Indian Medicinal Plants, National Institute of Science Communication, New Delhi, 1997,3.

11. Essentials oils: www.bojeneen.net

12. Bent $\mathrm{H}$ Havsteen, the biochemistry and medical significance of the flavonoids pharmacology \& therapeutics.2002; 96: 2-3.

13. Th. Weevers, Flowers Colours And Their Frequency, Acta Botancia Neerlanica,2013; 1(1):81-92.

14. Sharma Yashaswani, Hedge R.V., Venugopal C.K. Health \& Nutritional from ornaments, International Journal of Research in Ayurveda \& Pharmacy, 2(2):375-82 2011.

15. Pollen grains, www.biologydiscussion.com

16. Pollen, http://www.heakthline.com 
17. Chemical constituents of pollen, http://www.graminex.com/clinicalstudies.php.

18. https//www.theflowerexpert.com,www.holisticmindbody.healing.co $\mathrm{m}$

19. Ashutosh kar, Medicinal chemistry. 2010; 90.

20. Veber et.al., Journal of Medicinal Chemistry. 2002.
21. https://en.m.wikipedia.org/wiki/Pharmacophore

22. AkshayNegi "Hair related physhosocial pharmaceuticals" M.Sc. Pharm.chem. Thesis submitted to H.N.B. Garhwal University, Srinagar, Garhwal Uttarakhand, India.2007; 38-52.

23. AkshayNegi \& Dr. Luv kush "Tricophoric Ayurvedicophore”. IJIRD 2013; (2)7:127-131

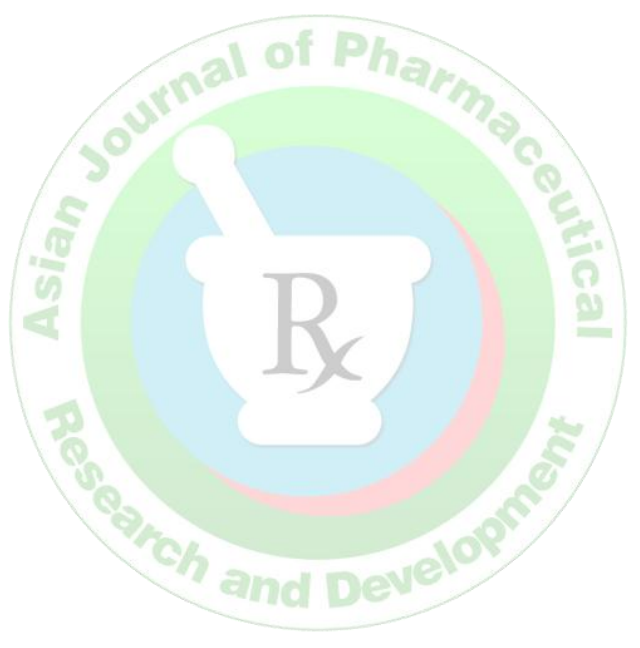

